\title{
Fearing the stranger? Homiletical explorations in a fear-filled world
}

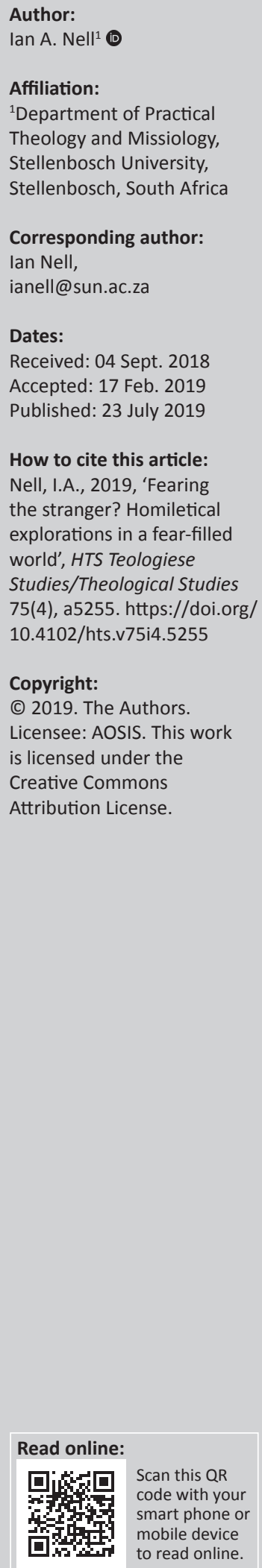

The large number of xenophobic attacks that broke out in different places in South Africa during 2008 was still continuing unabated 10 years later. We were stressed to come to terms with the reality that this occurred in a country that is globally considered to be an example of reconciliation. It is clear that we were confronted by the politics of fear, which were manifested in xenophobia and all the other -isms. In this article, the primary causes of these xenophobic outbreaks were scrutinised and placed within the wider framework of a culture of fear. The central research question is: Why are we still struggling with this phenomenon more than a decade after it first appeared on South African soil? In-depth analysis will be performed on what is lying behind the culture of fear underlying these acts of violence. After exploring some of the factors related to a culture of fear by making use of a sociological frame, the author moved on to answer a second question: How do we, as preachers, researchers and practical theologians, respond in a theological way to the challenges posed by a xenophobic culture in our preaching activities? Finally, the impact of violence and fear on the practice of preaching within a Christian context was discussed.

Keywords: Xenophobia; Practical theology; Homiletics; Culture of fear; Politics of fear.

\section{Introduction}

On Madiba's 100th birthday, we now stand at a crossroads, a moment in time in which two very different visions of humanity's future compete for the hearts and minds of citizens around the world. Two different stories, two different narratives, about who we are and who we should be.

\section{Barack Obama}

Speech commemorating Mandela's legacy, 17 July 2018 (Obama 2018:1)

The world celebrated the legacy and memory of one of Africa's most illustrious leaders, Nelson Rolihlahla Mandela, on 18 July 2018, just 2 weeks ago. The last few months have been special because it is the centenary celebration of his birth. His leadership was significant in reprioritising humanity and dignity by accentuating reconciliation and forgiveness, respect for all, the protection of human rights and equal opportunity (Edwards \& Juliet 2017:2). Thabo Leshilo asked Cheryl Hendricks and Keith Gottschalk to reflect on Barack Obama's speech ${ }^{1}$ commemorating Mandela's legacy by asking: What are the three most important things to take away from the speech?

Cheryl Hendricks: His key points were firstly that we are at a crossroads. What we have built and achieved over the last 100 years is being contested by those who espouse the politics of fear and resentment, fueled by the contradictions of globalization, failures of governance and political elites that have assumed a monopoly of power. This is manifested in xenophobia, terrorism, chauvinism, narrow nationalism, gender inequality, economic greed and authoritarianism. It's in direct opposition to the values, ideals and principles embodied by Madiba and the many who fought for democracy and freedom. It is uncertain which one will win, but we need to resist the cynicism, the divisions, hatred, corruption and be guided by universal principals, love, and servant collective leadership. Gottschalk: We have to address the fears of those who feel left out or left behind by globalization. We must work harder and smarter to realize Madiba's vision for freedom. (Hendricks \& Gottschalk 2018:1)

From Obama's speech it is very clear that we are confronted by the politics of fear, which are manifested in xenophobia and all the other -isms he refers to. Before we start reflecting on a culture of fear and xenophobia, I think it might be worthwhile to attempt to define fear.

1.The title of the address by President Barack Obama was Renewing the Mandela legacy and promoting active citizenship in a changing world.

Note: HTS 75th Anniversary Maake Masango Dedication. 


\section{On defining fear}

Martha Nussbaum recently (2018) published a volume on fear with the title The Monarchy of Fear: A Philosopher Looks at Our Political Crisis. Christopher Borelli (2018:1) from the Chicago Tribune asked her in an interview on her book: 'What is fear?' She answered as follows:

Fear is the sense that there are things that are bad for you and your well-being, looming over you, and you are not fully in control of warding them off. That is how Aristotle defines fear and what everyone agrees on. Fear can also be archaic and infantile. We have fear as soon as we are born, we are born into a state of physical helplessness. Humans can't do anything to get what they want for quite a long time. Unlike horses we can't even stand. So we are in a state of constant fear - 'Will I ever have my hunger assuaged?' It leaves a mark. Then we learn we will die. We learn early on, and fear never goes away, we are all powerless over it. So fear can be easily hijacked and grow out of control - arguably more so than other emotions, I would argue.

She further discusses aspects of fear and shows how often fear comes with a narrow self-interest that can include things such as one's family, city or country. She points out that fear often leads to anger and that one can then be under the wrong impression that one is in charge of one's fear. Fear also brings other emotions such as jealousy and despair to the surface, which means we do not want other people to enjoy the good things in life. Having some understanding of fear, we can now move on to a culture of fear.

\section{A culture of fear}

The first thing one realises when thinking and reflecting on the xenophobia that President Obama spoke about is that it is sustained by a culture and politics of fear and is not a phenomenon restricted to South Africa. We find a culture of fear all over the globe and it is normally associated with the workplace, politics and the impact of the media and publications (Higgs 2005:1). In 2013, the French-Algerian artist Kader Attia, who lives in Algiers and Berlin, titled his work The Culture of Fear: An Invention of Evil, and it was shown as part of Attia's major exhibition at the Museum of Contemporary Art in Sydney, Australia (Fahd 2017).

He was born in France in 1970 and grew up travelling between his ancestral home of Algeria and his birthplace in the suburbs of Paris. In the catalogue interview with the exhibition's curator, Attia tells of being part of two cultures, citing this experience as the basis of his practice. The Culture of Fear is a kind of library, displaying images and illustrations from 19th, 20th and 21st century books, newspapers and magazines. These are hung from hardware variety steel shelves usually synonymous with household garages. In Attia's creation the shelves are interlocked and transformed into dangerously high towers, evoking New York's Twin Towers. (p. 1)

One realises that a primary source for this fear relates to the horror of the $9 / 11$ event in the USA, but Attia's work prompts one 'to distinguish between the perpetrators' acts, the images of this terror then produced and disseminated en masse, and the effect the images have in creating dangerously divisive stereotypes' (Fahd 2017:3). He writes that today's culture of fear did not start with the 9/11 events, but was with us all along and is shaped by cultural suppositions about human vulnerability. In a recent article, Robinson (2018:3) writes about white American Protestant evangelicals, who voted for Trump because ' $t]$ hey feared that immigration was destroying America's European heritage, and that as white Protestantism waned, democracy itself would collapse'.

\section{Structure of the argument}

This article also concentrates on fear, but in this case on the 'fear of the stranger', particularly from a South African point of view. I will start with some general comments on the phenomenon of xenophobia within the context of fear and violence in South Africa, trying to answer the question: Why are we still struggling with this phenomenon more than a decade after it first appeared on South African soil? I will be looking at what is lying behind the culture of fear underlying these acts of violence. After exploring some of the factors related to a culture of fear by making use of a sociological frame, I want to move on and try to answer a second question: How do we, as preachers, researchers and practical theologians, respond in a theological way to the challenges posed by a xenophobic culture in our preaching activities?

In his reflection on xenophobic violence, Chris Kenyon (2008) came to the conclusion that 'we are a sick society':

If we judge South African society by this measure, the brutal beatings, burnings and displacements of our emigrant communities over the past few weeks must suggest that we are still a sick society. Responsibility for the wave of xenophobia sweeping across South Africa has been laid at the feet of various factors and actors: criminal groups, our present and past governments for lack of service delivery, and institutions responsible for law and order. (p. 531)

While there might be considerable truth in some of these perspectives, it is important that in our reaction as practical theologians we look for wider reasons. This raises many questions, such as: What is behind all of this? What are we grappling with here? What are the reasons? To be honest, we do not know yet. What we do know, is that this is a complex phenomenon with various possible descriptions. But that does not remove our accountability to search for some deep causes. The following is an effort to trace some of these reasons.

\section{Mapping the pattern of a xenophobic culture}

Many motives for this life-threatening form of social exclusion have been offered. Explanations for xenophobic prejudice often focus on three types of factors (Crush \& Pendelton 2007):

(a) interactive factors related to the amount of exposure inhabitants have to strangers, (b) cultural factors, which include identity and nationalism, and (c) material or economic factors related to employment opportunities, available resources, and so forth. (p. 75) 
A useful starting point in illuminating the causes of this endemic xenophobia map out the pattern of xenophobia. With this in mind, I want to use an adapted version of the work of Van der Ven (1993) ${ }^{2}$ in distinguishing between factors relating to identity, integration, politics and economics that can help us in identifying a pattern of some of the complexities involved in a xenophobic culture.

\section{Factors related to identity}

The first factor is identity and the word 'latency' is used as descriptor to show that norms, values and convictions are lying latent under the surface of society until a crisis breaks out or a conflict is experienced (Van der Ven 1993:69). It is then that the norms, values and convictions awake and start to play an important role. To begin with, it is difficult to understand the current crisis with xenophobia without carefully accounting for the cultural-historical past of our country; in other words, for the issues involving the identity and culture of our country's various population groups (Terblanche 2002:144).

Here we think about South Africa's colonial past, which is long not over yet. British colonialisation formed the basis for further political and economic development of the Cape from 1806 onwards. Western Europe exported modernity to Africa and other regions through colonisation during the 19th century and the first half of the 20th century. Included in these endeavours was the idea of the nation-state with one main language, a national education system, a developed economy and modern technology (Giliomee 2003:15). This led to economic impoverishment, inhuman treatment and cultural humiliation of South Africa's indigenous communities. Home-grown cultural norms were damaged to such a degree that it led to the biggest colonial heritage, namely the silent recognition of South Africa's imported colonial modernity as norm by people who were dishonoured by the system.

This silent recognition of modernism in its colonial cloak is characteristic of the African continent (Kobia, 2003:10). In South Africa, we find this in the activities of the two strongest indigenous political movements after they came into power, namely the Afrikaner and African nationalism. Both movements were of the opinion that liberation lay in taking the state over from the colonialists. This thought gained such momentum that both groups were prepared to turn to violence for pursuing that cause. What happened in the process was that the needed state and economic administration skills were not established and that the real challenge was only recognised later, namely how to reconcile imported colonial modernity with local needs.

A result of the aforementioned was that the new elite started to use the state as means of patronage for their ethnic

2.Van der Ven is seen as one of the most influential practical theologians of our time. $\mathrm{He}$ is recognised as one of the persons who contributed to the emancipation of $\mathrm{He}$ is recognised as on practical theology as a discipline in its own right. In his 1993 publication (Van de Ven 1993), he used the work of the sociologist Talcot Parsons $(1975,1979)$ to develop an ecclesiological framework. By making use of this framework he tried to come to a deeper understanding of the underlying factors at work in faith communities as organisations, concentrating on aspects such as identity, integration, politics and economics. supporters. By taking this route, the previous colonial elite was simply substituted as conduit to local wealth, but with very few changes in the financial policy and the lives of the majority of residents. This was the case with both the African National Congress and the National Party.

Without going into unnecessary detail, the results are very clear in South Africa today. Through affirmative action and black economic empowerment, a small but strong middle class has been developed. Unfortunately, in the lives of $60 \%$ of the poor people in our country very little changed, and most live in informal settlements and squatter camps (Kruidenier 2017:3). This state of affairs together with poor service delivery, ongoing poverty and a shaky infrastructure, gives one some understanding of the xenophobic attacks and associated violence. Black South Africans who are desperate and have rarely disclosed xenophobic behaviour in the past but who were left behind by the government turned on foreigners in their frustration and accused them of stealing their homes and jobs. It is very clear that we are dealing here with the actions of distressed victims seeking recognition by resorting to violence and exercising it on the weaker party (Edwards \& Juliet 2017:4).

\section{Factors related to integration}

The second factor is integration and this relates to the binding strength and cohesion in society. What are the things that bind people or hold them apart and what is the strength of the underlying social relations? How do people handle conflict and how is it resolved? What is the role of leaders in all of this? (Van der Ven 1993:69). It is well known that a spiral of violence has entrenched itself over a long period in our country. Theories underpinning this spiral of violence all start by pointing to the presence of 'institutional' or 'structural violence'. It is in other words about the radical disparities concerning opportunities, resources and privileges in society, kept together by different forms of power. One main example of this kind of violence is of course the ideology of apartheid (Smit 2007:5).

It is also further evident that this kind of violence is particularly widespread in deprived communities where people who are seen as strangers are attacked (Kenyon 2008:531). In Southern Africa, this 'baseline rate of violent crime' is one of the highest in the world (Watkins 2007:6). Swart (2008:313) states: 'There is a direct connection between poverty and the problems of violence, criminality and other social ills that are plaguing this society'. This all leads to different kinds of tension and works against processes that aim to promote social cohesion.

\section{Factors related to politics}

The third factor is politics and it relates to the concept of 'goal attainment', referring to that which one is striving for or what one wants to achieve in life. In other words, it is about the different actions one plans in reaching one's goals (Van der Ven 1993:69). We know that violent attacks on foreigners in 
South Africa did not occur out of the blue. They were the result of violent crime which, according to the Human Development Report 2016, was among the highest in the world (Jahan 2016:18). It was a planned and purposeful action by a number of people, including politicians and state officials.

According to Neocosmos (2008:587), xenophobia must be understood as a political discourse that is the result of a politics of fear that is widespread in both society and state. According to him, this politics of fear has at least three major components: 'a state discourse of xenophobia, a discourse of South Africa exceptionalism and a conception of citizenship founded exclusively on indigeneity' (Neocosmos 2006:587). He discusses each one of these factors in detail and I will try to summarise his argument briefly.

Concerning 'a state discourse of xenophobia', we find that government departments and especially the police have been reinforcing messages that we are being invaded by illegal immigrants who are a personal threat and a threat to national stability and the very fabric of our society. Already back in 1998, the Human Rights Watch (1998) concluded that:

in general, South Africa's public culture has become increasingly xenophobic, and politicians often make unsubstantiated and inflammatory statements that the 'deluge' of migrants is responsible for the current crime wave, rising unemployment and even the spread of diseases. (p. 4)

In this regard the press also played a huge part in contributing to a climate of fear of migrants through numerous news reports warning people that the migrants are flooding into the country to steal the jobs of the locals.

On the topic of 'a discourse of exceptionalism', Neocosmos (2008:590-591) writes that there is the idea that the country 'is not really in Africa and that its intellectual and cultural frame of reference is in the USA and Europe'. This attitude often stems from the idea that Africa is understood as the place of 'the other' and that what is happening in the rest of Africa (in terms of genocide and wars) could not possibly happen here. If you add to this the view that South Africa must be extraordinary as it is coveted by the rest of the world for having succeeded in running a successful reconciliation process, one can see what is meant by the discourse of exceptionalism.

Concerning 'the discourse of indigeneity', Neocosmos (2008:591-592) reflects on a letter that was written to the Mail $\mathcal{E}$ Guardian in which the author argued that black economic empowerment should be restricted to the indigenous, meaning that Indians and brown people should be excluded, being somehow less indigenous. It is also a common way in which many people argue in public while historically, the only truly indigenous people would be the San, with all the other groups migrating from the North.

It is clear from the above that xenophobia can be seen as a political discourse, but then one that has not been contested successfully and has been allowed to become hegemonic. According to Gous (2018:10), this is happening in a time of growing globalisation where we find a return to nationalism, creating a certain paradox in the sense that on the one hand, one finds more openness over boundaries, while on the other hand, one finds growing xenophobia and violence against immigrants.

\section{Factors related to economics}

The fourth factor is economics and the word 'adaptation' is used to describe the material needs that are necessary for survival. One needs financial provisions to adapt to changing circumstances (Van der Ven 1993:70). According to Wilkinson (2005:15), one of the main factors playing a role in xenophobic attacks is economic inequalities. He believes that greater income inequality leads to the escalation of social distance between the different income groups and that it also renders it difficult to develop a common and shared identity.

Vast differences in material wealth could also be seen as a difference in status as well as a difference in people's inherent worth. Where one finds communities where one's self-worth is determined by one's material wealth, it will happen that people finding themselves at the bottom end of the social hierarchy end up with low self-esteem and frustration because of exclusion from the different means of making a living. In this regard, it is normally young adult men who are prone to react on the slightest provocation. You also find with every outbreak of xenophobic violence in South Africa the refrain 'the kwerekwere are stealing our jobs', where kwerekwere can be translated as 'foreigners' (Wilkinson 2015:1).

Looking at the four factors, one finds a multi-layered and complex picture of the prevalence of xenophobia among South Africans, which brings us to the next question: How do we preach in a xenophobic culture?

\section{Preaching in a xenophobic culture}

In the introductory note on the conference on the website of Societas Homiletica, Dawn Ottoni-Wilhelm asks a number of questions related to the conference theme. The last question she asks is: 'How do we describe and develop homiletical spaces in which fear needs to be expressed?' (Societas Homiletica 2018:1). It is to this question that I want to respond in the second part of my own homiletical exploration. I want to propose that one way to approach an answer to this challenge is by putting the concept of reconciliation in the middle of the homiletical space. In concentrating on reconciliation, I want to open up at least three ways in which we can speak and preach about reconciliation within a xenophobic culture.

But before we get to that, first something about the importance of reconciliation. The South African Reconciliation Barometer Survey $^{3}$ is a nationally representative public opinion poll conducted annually by the Institute for Justice and Reconciliation (IJR). The barometer focuses on progress in

3.The South African Reconciliation Barometer Survey is a public opinion survey conducted by the IJR since 2003 . It is the only survey dedicated to critical measurement of reconciliation in South Africa, and is the largest longitudinal data source of its kind globally. 
reconciliation in South Africa. Key issues addressed in the survey include human security, political culture, political relationships, dialogue, historical confrontation and race relations. The barometer aims to gather how these aspects impact reconciliation in South Africa. It is a joint project of the Khayabus opinion poll of Ipsos-Markinor and the IJR, which collects data through interviews with a nationwide representative sample of 3487 South Africans. There is a presumption that $95 \%$ of the data is accurate and a possible deviation of $1.7 \%$ is calculated. The 2017 barometer indicated the following (Potgieter 2017):

- Many unresolved legacies of the apartheid and colonial eras remain. They continue to this day to present an obstacle in the way of achieving a truly fair and equitable society. As such, these legacies have to be confronted head-on and acknowledged.

- Despite some decline in the acknowledgement of the injustices of apartheid, a significant majority is still of the view that the apartheid system could be categorised as a crime against humanity.

- A majority of South Africans, furthermore, agree that the legacies of apartheid continue to persist to the present day, although differences between race groups are evident in this regard. Combined with perceptions of political and economic power and related fears born out of perceptions in this regard, unaddressed legacies remain divisive and limiting to reconciliation.

- Most South Africans feel that reconciliation is still needed, and that the Truth and Reconciliation Commission provided a good foundation for reconciliation in the country. However, just over half of the population feel that progress in terms of reconciliation has been made, while less than half of South Africans report having experienced reconciliation themselves. (pp. 7-8)

With these indicators in mind, I want to propose three ways in which preaching in a xenophobic context can benefit, namely through focusing on the logos, the pathos and the ethos of reconciliation.

\section{The logos of reconciliation - The triune God}

With the logos of reconciliation, I have in mind what we believe and why it ought to make sense for Christian believers in a homiletic context that is challenged by xenophobia. These include issues such as the following: What kind of theological discourse do we need in a country where there is so much distrust and misunderstanding? What vision and biblical images do we need to enter into dialogue about God, creation and humanity at this moment? How can a culture of fear be transformed into a culture of self-respect and human dignity? In other words, what would be the good news for the people of South Africa in a context of xenophobia?

The choice of reconciliation in this regard is not without certain risks. Hay (1998) wrote:

Religious groups, churches, political groups and others found it a convenient word on which to hang their ideological clothing.
The apartheid regime blithely used talk of reconciliation to maintain the status quo. On the other side, those in the struggle spoke about no reconciliation without justice. (p. 13)

Nevertheless, I agree with Rohr and Morell's view on reconciliation as a comprehensive concept for healing processes at different levels, including the entire cosmos and communities, and also on the personal level (2016:131-136). For the Christian tradition, reconciliation is the result of God's radical presence in the world through his Son and in the Spirit. In this regard, it serves as opposition to any form of exclusion, power abuse and alienation. Reconciliation seen in this way has its origin in God and finds its ultimate and final point of reference in the power of God's healing love and compassion with humankind. In one sense, one could say that it is the heart of the Christian faith community's identity, and we constantly need to be reminded of this through the act of preaching.

A metaphor often used in expressing the New Testament's alternative vision of reconciliation is the understanding of God as a living triune God. Volf (2010) uses the suffering of Christ to explain something about the internal dialogue within the Trinity and this eventually becomes the most decisive model for reconciliation. The cross, says Volf (2010:34), is 'giving up of God's self in order not to give up on humanity'. He develops his theology of embrace in terms of these two dimensions of the cross: the self-confessed love of Christ that overcomes human hostility and the creation of space in Godself to accept alienated humanity.

In light of the latter, we can say that the triune God is fully open and that there is equal power between God, Jesus and the Spirit while making in themselves space for the other. This necessarily leads to a dynamic understanding of our own identity that enables mutual non-hierarchical relationships and creates community - a community of mutual forgiveness and liberation, integrity and integration, wholeness and interdependence (Rohr \& Morrell 2016). Hereby we find a radical reinterpretation of power in the light of God's healing love and compassion, in God's impartiality and in his ability to reconcile and restore the dignity of life.

\section{The pathos of reconciliation - The liturgy}

In the logos of reconciliation, I propose an alternative vision for reconciliation by concentrating on the Trinitarian selfgiving of God embodied in Christ's suffering on the cross in order for us to live a reconciled life full of dignity. The questions are now: How does this alternative vision work in practice? What in our context can give a counter-experience to xenophobia and what impulses are powerful enough to move people to other insights?

In his book Desiring the Kingdom (2009), James Smith puts forward one alternative vision in very practical terms that can help create a counter-intuitive experience, helping us to move to new insights regarding a reconciled life. 
Smith explains passionately and in everyday language how worship contributes to the formation of our lives and how both can also be associated with education. He explains how the embodiment of God's love through Christ's suffering, which worship offers us, is central to a life of reconciliation. Therefore, our teaching and learning need to pay close attention to the ordering of our love, and by implication, also of our desires.

He also develops a new vision for higher education focusing on the fundamental desires of the heart. He describes very well how liturgies in our contemporary society are being worked out and performed in our churches, while the same underlying principles are also at work in sports arenas, shopping malls and even the world of work. He continues and re-imagines the Christian university not only as a place where students are busy with the formation of their thinking but also as a place where they ought to be taught to love the world in the right way. It stands in stark contrast to all our fears because we know from our tradition that love overcomes fear. The ordering of our love, therefore, starts with the order of the liturgy, and from there it flows into the ordering of our lives.

\section{The ethos of reconciliation - Integrity as liberating and healing ethos}

With the ethos of reconciliation we come to understand the acting individual who has to perform and take the lead, who has to convey the message of reconciliation with integrity and character on the basis of the correct ordering of his or her loves and desires. Rather than trying to provide a catalogue of virtues, I thought it best rather to return to the legacy of Nelson Mandela and to try to determine what made him such a remarkable leader and advocate for reconciliation. Hendricks (2018) summarises Mandela's leadership as follows:

Mandela was a humble, visionary leader of international stature seeking to bridge the divides between the North and the South to promote a common humanity, to reinvigorate multilateralism, to fight inequality and provide a moral compass for the world. His ideas about attaining peace in Africa through negotiations and mediation and creating more inclusive societies is one that still shapes conflict management on the continent. In South Africa his contribution remains his vision of a united, non-racial, nonsexist, democratic society that eschewed tribalism and patronage politics, and that promoted collective and servant leadership. He was a unifier in a deeply racially divided society. (p. 1)

In this context, it is not surprising that young people from across the continent of Africa are taking seriously the challenges Mandela posed for the next generation. In a recent article in The Conversation under the title 'How young activists are keeping Mandela's legacy alive across Africa', Alan Hirsch (2018) tells us that some of these young people are the leaders of powerful civil and political organisations and campaigns.

According to Hirsch, one such example is a person named Sampson Itodo, who succeeded in organising a campaign that would benefit young Nigerians in their pursuit of political positions. Itodo is one of a number of innovative, efficient young Africans who know Mandela's actions spoke louder than his words. For Itodo it became clear that Mandela was not at all interested in building some heroic cult around himself and that he also left explicit orders that he should not be treated as a half-god and that no statues should be erected for him. Of course, it has been ignored and today, more than 10 larger-than-life-sized statues of Mandela are found in some of the major cities in South Africa, not to mention all the statues of him around the rest of the globe.

To return to Itodo's story (Hirsch 2018):

On May 31 this year, Sampson's bill was passed overwhelmingly in the Nigerian Senate and House of Representatives. President Muhammadu Buhari signed it into law. Any Nigerian from the age of 35 can now run for President, and from 25 years for the House or State Assembly. (p. 3)

Itodo, however, did not drive the process on his own. He did it through hard work and by strategically mobilising and organising young people for 2 years - young people for whom representation was important and who wanted to have a voice in the political system, which many believed has failed. For someone like Itodo and many other young people on the African continent, Mandela's legacy and his belief in the power of young people's activities inspire them and keep them going.

\section{Conclusion}

I want to conclude by returning to Obama's speech where he in a very succinct way and almost in the form of a sermon points a way forward by keeping the tension between hope and fear (Obama 2018).

We have a better story to tell. But to say that our vision for the future is better is not to say it will inevitably win. Because history also shows the power for fear. History shows the lasting hold of greed and the desire to dominate others in the minds of men. Especially men. History shows how easily people can be convinced to turn on those who look different, or worship God in a different way. So if we're truly to continue Madiba's long walk towards freedom, we're going to have to work harder and we're going to have to be smarter ... I mean, it shows a poverty of ambition to just want to take more and more, instead of saying, 'Wow, I've got so much. Who can I help? How can I give more and more and more?' That's ambition. That's impact. That's influence. What an amazing gift to help people, not just yourself. And that's what we need right now, we don't just need one leader, we don't just need one inspiration, what we badly need right now is a collective spirit. (p. 1)

And the congregation respond ... 'Amen'.

\section{Acknowledgement Competing interest}

The author declares that no competing interest exists.

\section{Author contributions}

I declare that I am the sole author of this research article. 


\section{Funding}

Funding for this study was provided by the National Research Foundation.

\section{Data availability statement}

Data sharing is not applicable to this article as no new data were created or analysed in this study.

\section{Disclaimer}

The views and opinions expressed in this article are those of the authors and do not necessarily reflect the official policy or position of any affiliated agency of the authors.

\section{Ethical consideration}

This article followed all ethical standards for carrying out research without direct contact with human or animal subjects.

\section{References}

Borelli, C., 2018, 'Our summer of fear: A conversation with Chicago philosopher Martha Nussbaum', Chicago Tribune, 04 July, pp. 1-2.

Crush, J. \& Pendleton, W., 2007, Public attitudes toward immigration in the United States, France and Germany, Cambridge University Press, Cambridge.

Edwards, G. \& Peruma, J., 2017, 'Enacting social justice in education through spiritual leadership', Koers 82(3), 1-14. https://doi.org/10.19108/koers.82.3.2329

Fahd, C., 2017, 'Terror, Muslims, and a culture of fear: Challenging the media messages', The Conversation, 10 May, pp. 1-2.

Giliomee, H., 2003, The Afrikaners: Biography of a people, Tafelberg, Kaapstad.

Gous, A., 2018, 'Ons het nie nog 'n vader nodig [We do not need another father]', Beeld, 14 February, p. 10

Hay, M.O.M.I., 1998, Ukubuyisana: Reconciliation in South Africa, Cluster Publications, Pietermaritzburg.

Hendricks, C. \& Gottschalk, K., 2018, 'Obama pays tribute to Mandela: And invites the world to find its better angels', The Conversation, 17 July, pp. 1-2.

Higgs, R., 2005, Fear: The foundation of every Government's power, Independent Institute, Research article, viewed 20 July 2018, from http://www.independent. org/publications/article.

Hirsch, A., 2018, 'How young activists are keeping Mandela's legacy alive across Africa', The Conversation, 5 July, pp. 1-2.
Human Rights Watch, "'Prohibited Persons": Abuse of Undocumented Migrants, Asylum Seekers, and Refugees in South Africa', 1 March 1998, 1-56432-181-9, available at: https://www.refworld.org/docid/3ae6a8430.html [accessed 4 July 2018]

Jahan, S. (ed.), 2016, Human Development Report 2016: Human development for everyone, United Nations Development Programme, New York.

Kenyon, C., 2008, 'What do the xenophobic attacks reveal about the health of South African society?', South African Medical Journal 98(7), 1-4.

Kobia, S., 2003, The courage to hope: The roots for a new vision and the calling of the church in Africa, WCC Publications, Geneva.

Kruidenier, R., 2017, 'Personal encounters with children in an informal settlement: Exploring spirituality', Verbum et Ecclesia 38(1), a1632. https://doi.org/10.4102/ ve.v38i1.1632

Neocosmos, M., 2008, 'The politics of fear and the fear of politics: Reflections on xenophobic violence in South Africa', Journal of Asian and African Studies 43(6), 586-594. https://doi.org/10.1177/0021909608096655

Nussbaum, M., 2018, The monarchy of fear: A philosopher looks at our political crisis, Oxford University Press, Oxford.

Obama, B., 2018, 'Renewing the Mandela legacy and promoting active citizenship in a changing world', Speech Commemorating Mandela's Legacy, 17 July 2018, viewed 02 August 2018, from https://www.news24.com/Columnists/.

Parsons, T., 1975, 'The present status of "structural-functional" theory in sociology', in Coser, L.A. Social systems and the evolution of action theory, pp. 67-84, The Free Press, New York.

Parsons, T., 1979, 'An approach to the theory of organizations', Organizational Science 13(1), pp. 16-25.

Potgieter, E., 2017, 'South African Reconciliation Barometer Survey: 2017 report', viewed n.d., from https://www.ijr.org.za/portfolio-items/south-africanreconciliation-barometer-survey-2017-report/.

Robinson, M., 2018, 'What it means to be a Christian in America today', The Conversation, 19 June, pp. 1-2.

Rohr, R. \& Morrell, M., 2016, The divine dance: The trinity and your transformation, Whitaker House, Kensington, PA.

Smit, D.J., 2007, 'Mainline Protestantism in South Africa - And modernity? Tentative reflections for discussion', in International and Interdisciplinary Meeting on Religion and Development: Crisis or New Opportunities?, Free University, Amsterdam, Netherlands, June 14-15.

Smith, J.K., 2009, Desiring the kingdom (Cultural liturgies): Worship, worldview, and cultural formation, Baker Academic, Ada, Michigan.

Societas Homiletica, 2018, Conference theme: Fearing God in a fear-filled world: Homiletic explorations, viewed 25 July 2018, from http://www.societashomiletica.org/category/conferences/2018-durham-nc/.

Swart, I., 2008, 'Meeting the challenge of poverty and exclusion: The emerging field of development research in South African practical theology', International Journal of Practical Theology 12(1), 104-149. https://doi.org/10.1515/IJPT.2008.6

Terblanche, S., 2002, A history of inequality in South Africa 1652-2002, University of Kwazulu-Natal Press, Pietermaritzburg.

Van der Ven, J.A., 1993, Ecclesiologie in context, J.H. Kok, Kampen.

Volf, M., 2010, Exclusion \& embrace: A theological exploration of identity, otherness, and reconciliation, Abingdon Press, Grand Rapids, MI.

Watkins, K. (ed.), 2007, Human Development Report 2007/2008: Fighting climate change: Human solidarity in a divided world, Palgrave Macmillan, New York.

Wilkinson, K., 2015, 'South Africa's xenophobic attacks: Are migrants really stealing jobs?', The Guardian, 20 April, pp. 1-2.

Wilkinson, R., 2005, The impact of inequality, The New Press, New York. 